\title{
L-Glutathione Oxidized in the System of Redox Regulation of Cellular Functions
}

\author{
Vadim S Isachenko'*, Lubov V Minaeva ${ }^{2}$, Ksenia V Vinichenko ${ }^{1}$ and Alexandra V Rulish ${ }^{1}$ \\ ${ }^{1}$ Department of Otorhinolaryngology, SM Kirov Military medical academy, Russia \\ ${ }^{2}$ Department of Clinical biochemistry and laboratory diagnostics, SM Kirov Military medical academy, Russia
}

*Corresponding author: Vadim S Isachenko, Department of Otorhinolaryngology, SM Kirov Military medical academy, Russia

\begin{tabular}{|c|c|}
\hline ARTICLE INFO & ABSTRACT \\
\hline Received: 閏 July 12, 2019 & Citation: Vadim S Isachenko, Lubov V Minaeva, Ksenia V Vinichenko, Alexandra V Rulish. \\
\hline Published: 㓞 July 25, 2019 & $\begin{array}{l}\text { L-Glutathione Oxidized in the System of Redox Regulation of Cellular Functions. Biomed J } \\
\text { Sci \& Tech Res 20(1)-2019. BJSTR. MS.ID.003391. }\end{array}$ \\
\hline
\end{tabular}

\section{Introduction}

L-Glutathione oxidized (GSSG) is one of the key effectors in the system of redox regulation of cellular functions. GSSG functions in combination with a molecule of reduced glutathione (GSH), forming a redox pair of GSH / GSSG, present in all cells of multicellular organisms, in almost all known pathogenic microorganisms. The results of diverse studies of recent decades indicate that the functioning of the evolutionarily conservative glutathione cycle in prokaryotic and eukaryotic cells is aimed at

ensuring redox regulation of the activity of extracellular, surface cell and intracellular receptors and enzymes, ion channels and proteins transporters of cytoplasmic and intracellular membranes, extracellular regulators and intracellular membranes, extracellular regulators and transport peptide molecules, extracellular matrix proteins, cytoskeleton, etc. The mechanism of redox regulation of cellular functions involving GSH / GSSG exemplified by receptors and bioregulators is illustrated in Figure1.
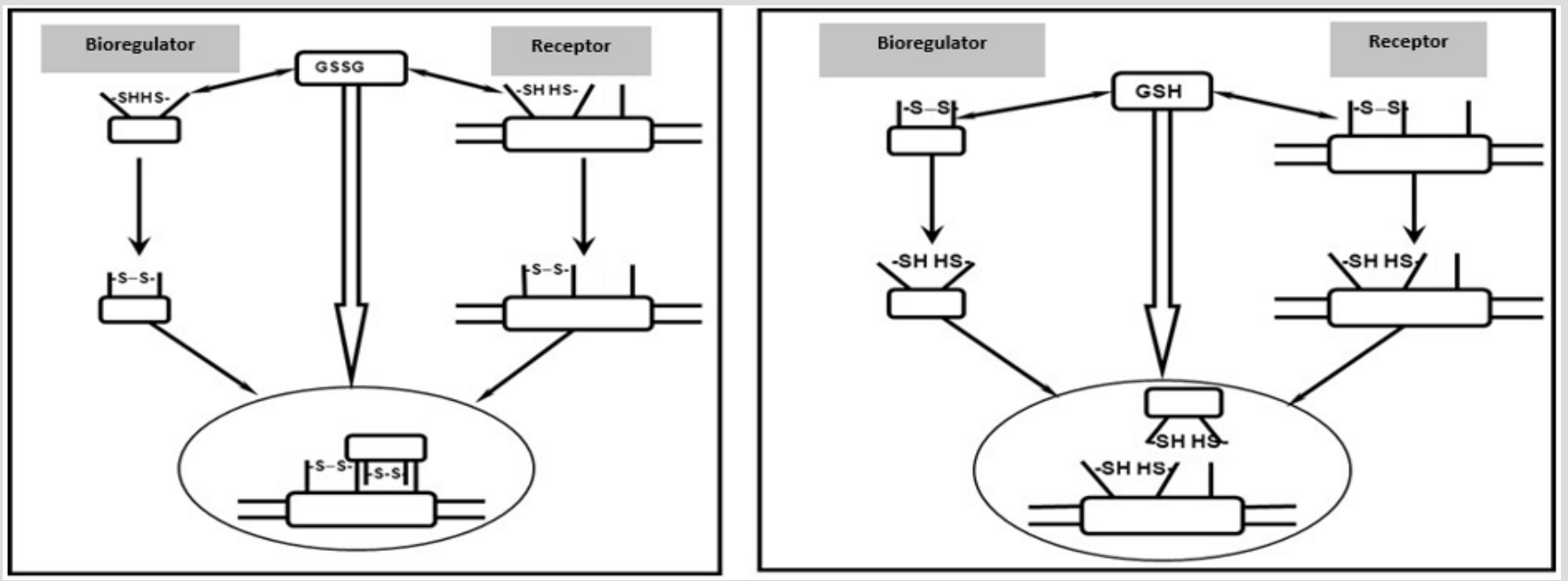

Figure 1: The principle of redox regulation involving GSH / GSSG exemplified by receptors and bioregulators. 
a) The effect of oxidized glutathione (GSSG) on sulfhydryl groups in the structure of functionally inactive extracellular bioregulators of peptide nature and / or their cell surface receptors leads to the oxidation of sulfhydryl groups (-SH) composed of receptor molecules and bioregulators, forming a functionally active conformation.

b) The effect of reduced glutathione (GSH) on disulfide cross-links in the structure of functionally active extracellular bioregulators of peptide nature and / or their surface-cell receptors leads to the restoration of disulfide crosslinks (-GS-

SG-) composed of receptor molecules and bioregulators and the formation of a functionally inactive conformation limiting physiologically adequate interactions.

The possibility of redox modification of sulfur residues in cysteines of evolutionarily conserved domains of peptide molecules of various functional purposes and in various biological structures in the extracellular and intracellular spaces allows regulatory redox effects on cells of the tissue or organ of the organism as a whole, which is determined by the redox environment of the cells in the limits of the corresponding morphological formation. The reduced glutathione predominates both intracellularly and extracellularly, but the ratio of GSH / GSSG in the microenvironment of cells and in a number of intracellular organelles is slightly lower than the intracellular value in the cytosol. As a result, the environment of the cells and the environment of a number of intracellular organelles are characterized by a greater oxidizing ability in comparison with cytosol.

An important feature of extracellular concentrations of GSH and GSSG is the dependence on the metabolic activity of the cell,

ISSN: 2574-1241

DOI: 10.26717/BJSTR.2019.20.003391

Vadim S Isachenko. Biomed J Sci \& Tech Res

This work is licensed under Creative Commons Attribution 4.0 License

Submission Link: https://biomedres.us/submit-manuscript.php which determines the intracellular content of glutathione and the possibility of their transport into the extracellular space (ATPdependent processes). Only reduced glutathione and / or its constituent amino acids can be transported back to the cell. Thus, the extracellular content of GSSG is determined by the intensity of the intracellular synthesis of GSH, the formation of glutathione disulfide fraction from it, their release (GSH and GSSG) into the extracellular medium and the subsequent return to the cells as a whole GSH molecule or its fragments. The extracellular degradation of GSH is affected by a membrane-bound enzyme - gamma-glutamyl transferase (GGT - KF2.3.2.2). The whole process requires energy and, in general, it resembles a useless (futile) cycle. However, the whole cycle or its individual elements are found in all living organisms containing GSH and GSSG. Its structure is evolutionarily conservative.

The dependence of the extracellular redox environment on the metabolic activity of the cell allows the cell to control the level of its participation in the function of the organ, tissue, organ system and the body as a whole. In pathological processes, ATP deficiency formed in the cell violates the situation-based pattern of cell's participation in the function of the organ, organ system, and organism as a whole. Considering the peculiarities of metabolism in pathological processes that determine the increased regenerating ability of the medium, the cells lose the ability to fully perform the function (see Figure 1). For the full situation-based participation of the cell in the function of a tissue or organ, it is necessary to restore the oxidizing ability of the medium and, accordingly, the functional activity of the surface cell structures - receptors, ion channels, transport proteins.

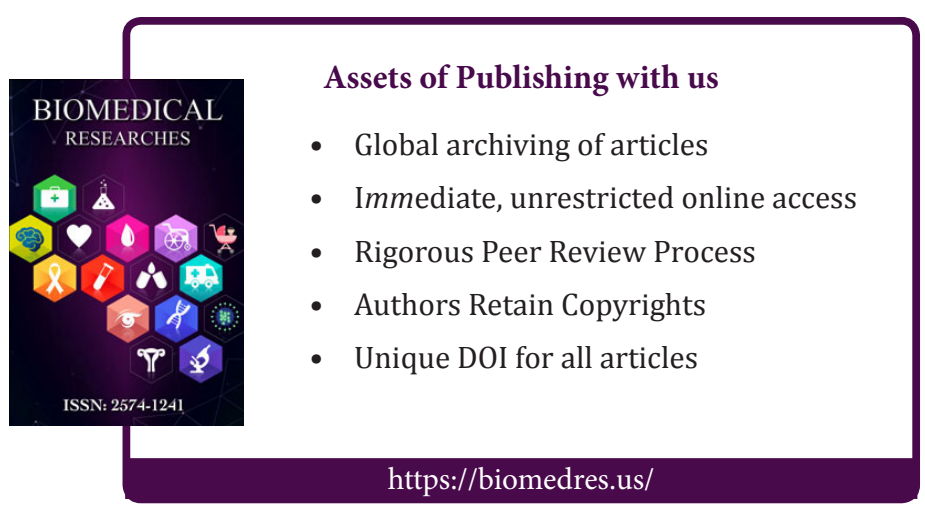

Copyright@ Vadim S Isachenko | Biomed J Sci \& Tech Res | BJSTR. MS.ID.003391. 